\title{
DIVERSIDADE GENÉTICA DE CLONES DE BANANEIRA 'PRATA-ANÃ' (AAB) POR MEIO DE MARCADORES SSR'
}

\author{
SAMIRA SANTIAGO LIBRELON², MÁRCIA REGINA COSTA3, \\ SILVIA NIETSCHE ${ }^{3}$, MARLON CRISTIAN TOLEDO PEREIRA ${ }^{3}$
}

RESUMO - Diversidade genética de 20 clones de 'Prata-Anã Gorutuba', quatro clones de 'Prata-Rio', quatro clones de 'Prata-Catarina' e as cultivares Caipira, Thap Maeo, Tropical, Maçã e Prata-Anã Comum foi avaliada por meio de marcadores moleculares Simple Sequence Repeats. De um total de 19 pares de primers SSRs utilizados, 57,8\% deles amplificaram bandas polimórficas e distintas, $26,3 \%$ não produziram produtos específicos e 15,7\% apresentaram falhas na amplificação de alguns indivíduos. O dendrograma indicou a formação de dois grupos. O primeiro grupo com a cultivar triploide Caipira, genoma exclusivamente A; enquanto o segundo (formado por sete subgrupos) agrupou todas as cultivares resultantes da hibridação natural ou artificial entre Musa acuminata e M. balbisiana, o subgrupo II, Tropical (AAAB) e o subgrupo III, Maçã (AAB). Os subgrupos IV, V, VI e VII foram formados, respectivamente, por: 'Prata-Catarina' clones 1 e 2; 'Prata-Rio' clones 1 e 2; 'Prata-Catarina' clone 3; 'Prata-Gorutuba' clones 12 e 17, 'Prata-Catarina' clone 4, 'Prata-Rio' clone 4, 'Thap Maeo' e 'Prata-Anã'. O subgrupo VIII foi formado exclusivamente pelos clones de’ Prata-Anã Gorutuba'. Os resultados indicam a eficiência dos marcadores microssatélites na discriminação e na caracterização dos clones da 'Prata-Anã Gorutuba' da cultivar Prata-Anã.

Termos para indexação: Musa spp. microssatélites, similaridade, cultivares.

\section{GENETIC DIVERSITY OF 'PRATA ANÃ' (AAB) BANANA TREE CLONES BY USING SSR MARKERS}

\begin{abstract}
Genetic diversity of 20 'Prata Anã Gorutuba' banana clones, four 'Prata Rio' clones, four 'Prata Catarina' clones and the cultivars Caipira, Thap Maeo, Tropical, Maçã and Prata Anã was evaluated by using Single Sequence Repeats markers. Of a total of 19 SSR's primers used 57.8\% amplified polymorphic and distinct bands, $26.3 \%$ did not amplified specific bands and $15.7 \%$ failed the amplification. Two groups were obtained. The first group was formed by triploid cultivar Caipira that contain exclusively the genome A. The second of cultivars and clones originated from natural or artificial hybridization between Musa acuminata and M. balbisiana were grouped in seven subgroups. The cultivars Tropical (AAAB) and Maçã (AAB) formed the subgroups II and III, respectively. The subgroups IV, V, VI, and VII were formed by: 'Prata Catarina' clones 1 and 2; 'Prata Rio' clones 1 and 2; 'Prata Catarina' clone 3; 'Prata Gorutuba' clone 12 and 17, 'Prata Catarina' clone 4, Prata Rio clone 4 and the cultivars Thap Maeo and Prata Anã. The subgroup VIII was formed exclusively by Prata Gorutuba clones. The SSR marker was efficient in characterization and discrimination of 'Prata Gorutuba' clones from cultivar Prata Anã.
\end{abstract}

Index terms - Musa spp., microsatellites, similarity, cultivars.

${ }^{1}$ (Trabalho 023-13). Recebido em: 03-01-2013. Aceito para publicação em:16-08-2013

${ }^{2}$ Engenheira Agrônoma, Mestranda em Genética e Melhoramento de Plantas, UFLA, Departamento de Biologia, Caixa Postal 3037 , CEP 37200-000. E-mail: salibrelon@yahoo.com.br

${ }^{3}$ Engenheiros Agrônomos, Professores do Departamento de Ciências Agrárias, Universidade Estadual de Montes Claros - Unimontes, Janaúba-MG, CEP 39440-000. E-mail: marcia.costa@unimontes.br, silvia.nietsche@unimontes.br, marlon.pereira@unimontes.br 


\section{INTRODUÇÃO}

Os principais polos brasileiros de produção de banana são: norte de Minas Gerais, sudoeste e Vale do São Francisco, na Bahia, Vale do Ribeira no Estado de São Paulo, litoral norte e Vale do Itajaí em Santa Catarina e Vale do Açu no Rio Grande do Norte. Destes, merece destaque o norte de Minas Gerais por produzir basicamente a cultivar Prata-Anã (RODRIGUES et al., 2011).

Dentre as fontes de geração de variabilidade genética na cultura da banana, citam-se as mutações naturais e as variações somaclonais provenientes do cultivo in vitro (SONIYA et al., 2001). Os mutantes e os variantes somaclonais são considerados importantes fontes de variabilidade e podem ser usados de maneira direta ou indireta em programas de melhoramento para desenvolvimento de novas cultivares ou, ainda, na seleção de clones superiores de banana (HWANG; KO, 2004).

$\mathrm{Na}$ cultura da banana, diversas cultivares e clones cultivados atualmente surgiram por meio de mutações. Dentro do grupo Cavendish, a cultivar Nanicão teve sua origem via mutação natural da cultivar Nanica, enquanto a Nanicão Corupá é um clone oriundo de uma variação natural no campo. No grupo Prata, a cultivar Prata-Anã ('Enxerto') surgiu no início do século XX, no sul de Santa Catarina, a partir de uma mutação da banana 'Branca', e a Prata- Catarina é um clone e teve sua origem no ano de 1997, a partir de uma variação natural da 'Prata-Anã' (CRESTE et al., 2003; MOREIRA; LICHTEMBERG, 2006). A introdução da cultivar Prata-Anã no norte do Estado de Minas Gerais ocorreu na década de 1990, e, a partir daí, inúmeros variantes somaclonais vêm sendo selecionados pelos produtores (MOREIRA; LICHTEMBERG, 2006; LICHTEMBERG; LICHTEMBERG, 2011).

Variantes somaclonais conhecidos popularmente por 'Prata-Anã Gorutuba' vem sendo identificados por meio do uso dos descritores morfológicos e moleculares. Rodrigues et al. (2012) demonstraram em seu estudo que a presença de antocianina no pseudocaule, a forma do cacho e a flexão das pencas permitiram diferenciar de maneira clara os clones de 'Prata-Anã Gorutuba' da cultivar comercial Prata-Anã.

A avaliação da variabilidade fenotípica e a caracterização de germoplasma de Musa spp. estão baseadas no uso de caracteres fenotípicos (IPGRI, 1996), entretanto vários autores apontam algumas desvantagens associadas ao uso desta metodologia, como: os marcadores fenotípicos são em número limitado, afetados pelo meio ambiente, apresentam variação contínua e alto grau de plasticidade, podendo, muitas vezes, não refletir a real diversidade existente (BOUHADIDA et al., 2009).

Em contraste com os marcadores morfológicos, os marcadores moleculares podem revelar diferenças entre os genótipos em nível de DNA, permitindo uma caracterização direta e eficiente, suficiente para discriminar a variação genética existente entre indivíduos e dentro de populações (WANG et al., 2010). Dentre os marcadores existentes, os microssatélites (SSR) têm sido considerados os ideais para a caracterização e a avaliação da variabilidade genética, são abundantes, dispersos ao acaso no genoma, lócus específico, codominantes e multialélicos. Suas aplicações nos estudos com banana incluem a genotipagem, taxonomia e evolução, e saturação de mapas de ligação (AMORIM et al., 2008;JESUS et al., 2009).

O presente estudo teve como objetivo avaliar a variabilidade genética em clones da bananeira 'Prata-Anã', Grupo (AAB), por meio do uso de marcadores microssatélites.

\section{MATERIAL E MÉTODOS}

\section{Coleta do material genético}

Amostras foliares de cinco cultivares: PrataAnã, Caipira, Thap Maeo, Tropical e Maçã e de vinte clones de bananeira 'Prata-Anã Gorutuba', quatro clones de 'Prata-Rio', quatro clones de 'Prata-Catarina' foram coletadas a partir de plantas adultas e enviadas ao Laboratório de Biotecnologia da Universidade Estadual de Montes Claros, Janaúba, Brasil (Tabela 1).

\section{Extração do DNA e condição de PCR}

O DNA dos genótipos foi extraído de folhas jovens, utilizando-se do método de brometo de hexadeciltrimetilamônio (CTAB), de acordo com a metodologia de Doyle e Doyle (1990). Um total de 19 pares de primers foram testados, compreendendo 10 desenvolvidos por Crouch et al. (1998), [série $\mathrm{Ma}$ ], 4 desenvolvidos por Lagoda et al.(1998) [série AGMI], 4 obtidos por Creste et al. (2006) [série MaOCEN ] e 1 par obtido por Kaemmer et al. (1997) [série STMS]. As reações de amplificação com os primers SSRs foram completadas para o volume final de $15 \mu \mathrm{L}$, contendo: $\mathrm{KCl} 50 \mathrm{mM}$, Tris-HCl $10 \mathrm{mM}$ (pH 8,3), $\mathrm{MgCl}_{2} 2,5 \mathrm{mM}, 100 \mathrm{mM}$ de dNTPs, $0,2 \mu \mathrm{M}$ de cada primer, $50 \mathrm{ng}$ de DNA genômico e uma Unidade de Taq DNA polimerase (INVITROGEN-Life Tecnologies Brazil). As 
amplificações foram conduzidas em termociclador Techne, modelo TC-412, empregando-se um ciclo inicial de $94{ }^{\circ} \mathrm{C}$, por 3 min, seguido de 9 ciclos de touchdown de $40 \mathrm{~s}$, a $94{ }^{\circ} \mathrm{C} ; 40 \mathrm{~s}$ a $60{ }^{\circ} \mathrm{C}, 60 \mathrm{~s}$ a $72{ }^{\circ} \mathrm{C}$, reduzindo um grau a cada ciclo, seguido de 25 ciclos de $40 \mathrm{~s}$ a $94{ }^{\circ} \mathrm{C}, 40 \mathrm{~s}$ a $50{ }^{\circ} \mathrm{C}$ e $60 \mathrm{~s}$ a $72{ }^{\circ} \mathrm{C}$ e um ciclo final de extensão de $72^{\circ} \mathrm{C}$, por 4 minutos, seguido de um ciclo a $4^{\circ} \mathrm{C}$ até a retirada das amostras do termociclador.

Os produtos das amplificações foram separados por eletroforese em gel de poliacrilamida a $30 \%$, a $200 \mathrm{~V}$, em tampão TAE $1 \mathrm{X}$ e corados em solução de prata $\left(\mathrm{AgNO}_{3}\right)$ a $0,2 \%$, segundo metodologia de Beidler et al. (1982). Os fragmentos amplificados foram fotodocumentados utilizando um scanner.

\section{Análise dos dados}

Os dados obtidos por meio da eletroforese foram registrados na forma de presença e ausência de bandas. A distância genética entre os genótipos foi calculada com base no coeficiente de similaridade de Jaccard. De acordo com as distâncias genéticas, foi elaborado, pelo método do algoritmo Unweighted Pair Groups Method with Arithmetic Mean (UPGMA), um dendrograma. A estabilidade dos nós do dendrograma foi verificada pelo método de reamostragem com 1.000 bootstraps. Para a análise dos dados obtidos, foi utilizado o programa estatístico Genes (CRUZ, 2006). Foi calculado o Conteúdo de Informação de Polimorfismo (PIC), aplicando-se a fórmula: $\mathrm{PIC}=1-\sum \mathrm{pi}^{2}$, em que pi é a frequência do alelo i na população (WEILER, 2010).

\section{RESULTADOS E DISCUSSÃO}

Dos 19 pares de primers testados, $11(57,9 \%)$ deles amplificaram bandas polimórficas e distintas, cinco $(26,3 \%)$ não produziram produtos específicos e três $(15,8 \%)$ apresentaram falhas na amplificação de alguns indivíduos. A partir dos 11 pares de primers que produziram produtos polimórficos, 33 alelos foram obtidos, com média de 3 alelos por primer. $\mathrm{O}$ maior grau de polimorfismo foi obtido com o primer AGMI 24/25 (8 alelos), e o menor, pelo primer Ma 3/90 (1 alelo) (Tabela 2).

O conteúdo de informação de polimorfismo (PIC) variou de 0,03 para o primer $\mathrm{MaO} 1 \mathrm{G} 10$ a 1,48 para o primer AGMI 24/25, com média de 0,48 por primer (Tabela. 2). O primer Ma 1/17, apesar de apresentar 4 alelos, obteve valor do PIC igual a 0,22 , isto pode ser explicado pela alta frequência em que estes alelos se encontravam dentro da população $\left(\sum \mathrm{pi}^{2}=0,78\right)$. Já o primer $\mathrm{MaO} 2 \mathrm{C} 11$ apresentou apenas 2 alelos e obteve valor do PIC igual a 0,76 , pois estes dois alelos encontravam-se em baixa frequência dentro da população $\left(\sum \mathrm{pi}^{2}=0,24\right)$. Consequentemente, o primer $\mathrm{MaO} 2 \mathrm{C} 11$ apresenta maior capacidade de discriminar os genótipos que o primer Ma 1/17.

O primer AGMI 24/25 amplificou um alelo presente em todos os genótipos de bananeira triploides com o genoma $\mathrm{B}$, exceto no genótipo da cultivar Maçã (AAB). No genótipo da cultivar Tropical (AAAB), esse primer não demonstrou a presença desse alelo. A matriz de distância genética gerada pelo coeficiente de similaridade de Jaccard revelou variação de distância genética de 0 a $89 \%$ entre os genótipos com distância média de 40,77\%, revelando alta variabilidade genética entre os clones e cultivares avaliados. As maiores distâncias genéticas foram obtidas entre o clone de Prata-Catarina 1 e a cultivar Caipira, com $89 \%$ e $85 \%$ entre o clone de Prata-Rio 3 e a cultivar Caipira, e entre o clone de Prata-Rio 2 e a cultivar Caipira, e $81,81 \%$ entre o clone de Prata-Anã Gorutuba 13 e a cultivar Caipira.

As distâncias genéticas entre os clones de 'Prata-Anã Gorutuba' e a cultivar Prata-Anã, variaram de 23,81 a 45,45 \%, estando a 'Prata-Anã Gorutuba' (Clone 17) geneticamente mais próxima e a 'Prata-Anã Gorutuba' (Clone 13), e mais distante da cultivar 'Prata-Anã Comum'. A partir do dendrograma obtido pelas distâncias genéticas, pode-se verificar que os genótipos foram divididos em dois grandes grupos (Figura1).

O primeiro grupo contém a cultivar Caipira com genoma exclusivamente A (Grupo I); enquanto o segundo possui todas as cultivares e os clones resultantes da hibridação natural ou artificial entre Musa acuminata e Musa balbisiana. Subdividindo o segundo grupo, observa-se a formação de 7 subgrupos (II a VIII), totalizando 8 subgrupos.

Os subgrupos II e III foram formados apenas pelas cultivares Tropical (AAAB) e Maçã (AAB), respectivamente. Os subgrupos IV, V, VI e VII foram formados, respectivamente, por: 'Prata-Catarina' clones 1 e 2; 'Prata-Rio' clones 1 e 2; 'Prata-Catarina' clone 3; 'Prata-Anã Gorutuba' clones 12 e 17, 'Thap Maeo', 'Prata-Catarina' clone 4, 'Prata-Anã Comum' e 'Prata-Rio' clone 4. No subgrupo VIII, 90\% dos clones de 'Prata-Anã Gorutuba' agruparam-se, exceto os clones 12 e 17, agrupados no subgrupo VII.

A caracterização da variabilidade genética é de fundamental importância para o melhoramento de qualquer espécie. Prospecção, coleção e conservação de clones superiores, pertencentes ao genoma Musa 
spp. requerem atenção especial, visando à diminuição da erosão genética bem como à ampliação da utilização dos genótipos em futuros programas de melhoramento (VENKATACHALAM et al., 2007).

No presente estudo, por meio da amplificação com 11 primers SSR, foi obtida média de três alelos por primer. $\mathrm{O}$ número médio de alelos por primer SSRs obtido foi inferior ao de outros estudos realizados em banana. Entretanto, considerando a completa ausência de estudos com os clones avaliados, os resultados obtidos no presente estudo permitiram realizar com eficiência a caracterização dos clones de 'Prata-Anã Gorutuba'. Creste (2004), utilizou nove primers SSRs para genotipar 49 diploides, observando um total de 115 alelos, com média de 12,7 alelos por primer. Ning (2007), para genotipar 50 genótipos de bananeira de diferentes origens, utilizou 10 pares de primers SSR, encontrando 92 alelos, média de 9,2 alelos por primer. Estudo recente publicado por Wang et al. (2010) detectaram uma média de 3,76 alelos ao avaliar a variabilidade dentro de 26 cultivares de banana por meio do uso de 21 primers SSR.

A natureza codominante dos marcadores microssatélites constitui uma de suas maiores vantagens, quando comparado com outros métodos baseados em PCR, pois permite fazer estimativas das relações alélicas entre os indivíduos. Porém, alta proporção de alelos multiplex revelada pelos marcadores SSRs em espécies poliploides compromete a definição das relações alélicas entre os indivíduos. Além disso, o germoplasma de Musa possui natureza genômica complexa em todos os níveis de ploidia, envolvendo muitas duplicações cromossômicas, o que resulta na perda da natureza codominante dos marcadores SSRs (CROUCH et al., 1998).

O primer AGMI 24/25 apresentou valor do PIC maior que 1 , com um total de oito alelos. O valor do PIC varia geralmente de "0", para perfis monomórficos, até "1", para perfis altamente polimórficos. Entretanto, se houver mais de dois alelos por loco e estes encontrarem-se em heterozigose, o valor de PIC supera a unidade $(1,0)$. Assim, esse valor está relacionado com o número de alelos, que, por sua vez, está diretamente associado à divergência genética e ao número de genótipos em estudo (MALONE, 2007). Souza (2002) foi capaz de avaliar o nível de ploidia de $83 \%$ dos genótipos estudados por meio do uso do primer AGMI 24/25, permitindo ainda gerar um fingerprinting para todos os grupos genômicos.

Dentre os dois grupos formados, o grupo I e os subgrupos II e III agruparam apenas um genótipo cada, as cultivares: Caipira (AAA), Tropical (AAAB) e Maçã (AAB), respectivamente. Outros estudos conduzidos também demonstraram a capacidade dos microssatélites em discriminar genótipos com base no nível de ploidia e alelos específicos de cada genoma (CRESTE et al., 2003; JESUS et al., 2009).

$\mathrm{O}$ arranjo do dendrograma permitiu alocar todos os clones e variedades com origem em comum, mostrando a eficiência do marcador em discriminar genótipos por origem. Todos os clones avaliados no presente trabalho: clones da 'Prata-Anã Gorutuba", 'Prata-Rio' e 'Prata- Catarina', derivaram da mesma cultivar 'Prata-Anã' (CRESTE et al., 2003). Apenas a cultivar Thap Maeo, que se juntou ao subgrupo VII, não apresenta origem em comum com os demais genótipos, mas que também possui grupo genômico AAB. A variedade Thap Maeo foi introduzida da Tailândia e selecionada pela Embrapa Mandioca e Fruticultura Tropical, é uma variedade pertencente ao grupo $\mathrm{AAB}$, muito semelhante à 'Mysore', diferenciando-se desta, por não apresentar altas infestações de viroses (BSV). Apresenta frutos pequenos, resistência às Sigatokas negra e amarela $\mathrm{e}$ ao mal-do-panamá, além de ser uma variedade muito rústica (SILVA et al., 2004).

Para separar apenas o grupo genômico de bananeira, o RAPD foi eficiente (SOUZA et al., 2008); entretanto, para a caracterização molecular intravarietal, Jesus et al. (2009) recomendam a utilização de marcadores SSRs, que possuem expressão codominante, são multialélicos e apresentam alta repetibilidade, sendo ideais para a identificação e a discriminação de genótipos.

Dos 20 clones de 'Prata-Anã Gorutuba' avaliados, 18 agruparam-se no subgrupo VIII, indicando claramente um distanciamento genético dos clones designados popularmente por 'Prata-Anã Gorutuba' em relação à cultivar comercial Prata-Anã. A distância média entre os clones de 'Prata-Anã Gorutuba' em relação à 'Prata-Anã' foi de 37,41\%, sendo os clones 17 e 12 os que apresentaram menor distância, ficando esses no mesmo subgrupo da 'Prata-Anã' (Subgrupo VII).Quanto aos clones 'Prata-Rio' e 'Prata-Catarina', as distância médias entre os clones e a cultivar Prata-Anã foi de 35 e $44 \%$, respectivamente. Os clones 3 e 4 da 'Prata-Rio' e o 4 da 'Prata-Catarina' foram alocados no mesmo subgrupo da 'Prata-Anã'.

Embora Rodrigues et al. (2012), ao realizarem a caracterização de 45 clones de bananeira 'Prata-Anã' por meio do uso de marcadores RAPD, incluindo os clones estudados neste trabalho, tenham observado variabilidade entre os materiais, todos os clones avaliados agruparam-se com a cultivar Prata-Anã. 
Fato ocorrido, provavelmente, pela característica do marcador molecular utilizado (RAPD), que amplifica diferentes regiões do genoma (incluindo regiões de DNA repetitivo) de forma arbitrária.

TABELA 1- Nome popular, natureza, grupo genômico e local de coleta de 28 clones de bananeira 'PrataAnã' e as cultivares Maçã, Tropical, Thap Maeo, Caipira e Prata-Anã.

\begin{tabular}{|c|c|c|c|}
\hline Nome Popular & Natureza & Grupo Genômico & Município- Estado \\
\hline Prata-Anã Gorutuba & Clone 1 & $\mathrm{AAB}$ & Nova Porteirinha-MG \\
\hline Prata-Anã Gorutuba & Clone 2 & $\mathrm{AAB}$ & Nova Porteirinha- MG \\
\hline Prata-Anã Gorutuba & Clone 3 & $\mathrm{AAB}$ & Nova Porteirinha- MG \\
\hline Prata-Anã Gorutuba & Clone 4 & $\mathrm{AAB}$ & Nova Porteirinha- MG \\
\hline Prata-Anã Gorutuba & Clone 5 & $\mathrm{AAB}$ & Janaúba- MG \\
\hline Prata-Anã Gorutuba & Clone 6 & $\mathrm{AAB}$ & Janaúba- MG \\
\hline Prata-Anã Gorutuba & Clone 7 & $\mathrm{AAB}$ & Janaúba- MG \\
\hline Prata-Anã Gorutuba & Clone 8 & $\mathrm{AAB}$ & Janaúba- MG \\
\hline Prata-Anã Gorutuba & Clone 9 & $\mathrm{AAB}$ & Janaúba- MG \\
\hline Prata-Anã Gorutuba & Clone 10 & $\mathrm{AAB}$ & Janaúba- MG \\
\hline Prata-Anã Gorutuba & Clone 11 & $\mathrm{AAB}$ & Janaúba- MG \\
\hline Prata-Anã Gorutuba & Clone 12 & $\mathrm{AAB}$ & Janaúba- MG \\
\hline Prata-Anã Gorutuba & Clone 13 & $\mathrm{AAB}$ & Jaíba- MG \\
\hline Prata-Anã Gorutuba & Clone 14 & $\mathrm{AAB}$ & Jaíba- MG \\
\hline Prata-Anã Gorutuba & Clone 15 & $\mathrm{AAB}$ & Jaíba- MG \\
\hline Prata-Anã Gorutuba & Clone 16 & $\mathrm{AAB}$ & Jaíba- MG \\
\hline Prata-Anã Gorutuba & Clone 17 & $\mathrm{AAB}$ & Jaíba- MG \\
\hline Prata-Anã Gorutuba & Clone 18 & $\mathrm{AAB}$ & Jaíba- MG \\
\hline Prata Anã Gorutuba & Clone 19 & $\mathrm{AAB}$ & Jaíba- MG \\
\hline Prata-Anã Gorutuba & Clone 20 & $\mathrm{AAB}$ & Jaíba- MG \\
\hline Prata-Catarina 1 & Clone 1 & $\mathrm{AAB}$ & Jaíba- MG \\
\hline Prata-Catarina 2 & Clone 2 & $\mathrm{AAB}$ & Jaíba- MG \\
\hline Prata-Catarina 3 & Clone 3 & $\mathrm{AAB}$ & Jaíba- MG \\
\hline Prata-Catarina 4 & Clone 4 & $\mathrm{AAB}$ & Jaíba- MG \\
\hline Prata-Rio 1 & Clone 1 & $\mathrm{AAB}$ & Jaíba- MG \\
\hline Prata-Rio 2 & Clone 2 & $\mathrm{AAB}$ & Jaíba- MG \\
\hline Prata-Rio 3 & Clone 3 & $\mathrm{AAB}$ & Jaíba- MG \\
\hline Prata-Rio 4 & Clone 4 & $\mathrm{AAB}$ & Jaíba- MG \\
\hline Prata-Anã & Cultivar & $\mathrm{AAB}$ & Cruz das Almas- BA \\
\hline Maçã & Cultivar & $\mathrm{AAB}$ & Janaúba- MG \\
\hline Tropical & Cultivar & AAAB & Janaúba - MG \\
\hline Thap Maeo & Cultivar & $\mathrm{AAB}$ & Nova Porteirinha -MG \\
\hline Caipira & Cultivar & AAA & Nova Porteirinha -MG \\
\hline
\end{tabular}


TABELA 2 - Primers microssatélites, sequência do primer, temperatura de anelamento, número de alelos e Conteúdo de Informação de Polimorfismo (PIC) .

\begin{tabular}{|c|c|c|c|}
\hline Lócus SSR & Sequência do primer $\left(5^{\prime}-3^{\prime}\right)$ & Alelos & PIC \\
\hline Ma 1/17 & $\begin{array}{l}\text { F aggcggggaatcggtaga } \\
\text { R ggcgggagacagatggagt }\end{array}$ & 4 & 0,22 \\
\hline Ma 1/139 & $\begin{array}{c}\text { F actgctctccacctcaac } \\
\text { R gtcccccaagaaccatatgatt }\end{array}$ & 3 & 0,66 \\
\hline Ma 1.27 & $\begin{array}{l}\text { F tgaatcccaagtttggtcaag } \\
\text { R caaaacacatgtccccatctc }\end{array}$ & 2 & 0,66 \\
\hline Ma 3/48 & $\begin{array}{l}\text { F cccgtcccattttctcca } \\
\text { R ttcgttgttcatggaatca }\end{array}$ & 4 & 0,71 \\
\hline AGMI 33-33 & $\begin{array}{c}\mathrm{F} \text { agtttcaccgattggttcat } \\
\mathrm{R} \text { taacaaggactaatcatgggt }\end{array}$ & 3 & 0,30 \\
\hline Ma 3/90 & $\begin{array}{l}\text { F gcacgaagaggcatcac } \\
\text { R ggccaaatttgatggact }\end{array}$ & 1 & 0,17 \\
\hline AGMI $24 / 25$ & $\begin{array}{c}\text { F tttgatgtcacaatgggttcc } \\
\text { R ttaaaggtgggttagcattagg }\end{array}$ & 8 & 1,48 \\
\hline AGMI 103-103 & $\begin{array}{l}\text { F cagaatcgctaaccctatcctca } \\
\text { R ccctttgcgtgeccetaa }\end{array}$ & 2 & 0,2 \\
\hline AGMI 105-105 & $\begin{array}{l}\mathrm{F} \text { tcccaacccetgcaaccact } \\
\mathrm{R} \text { atgacctgtcgaacatccttt }\end{array}$ & 2 & 0,1 \\
\hline $\mathrm{MaO} 1 \mathrm{G} 10$ & $\begin{array}{l}\text { F tctcaggaagggcaacaatc } \\
\text { R ggaccaaagggaaagaaacc }\end{array}$ & 2 & 0,03 \\
\hline $\mathrm{MaO} 2 \mathrm{C} 11$ & $\begin{array}{c}\text { F ggaagaaagaagtggagaatgaa } \\
\text { R tgaaatggataaggcagaagaa }\end{array}$ & 2 & 0,76 \\
\hline Total & - & 33 & - \\
\hline Média & - & 3 & 0,48 \\
\hline
\end{tabular}




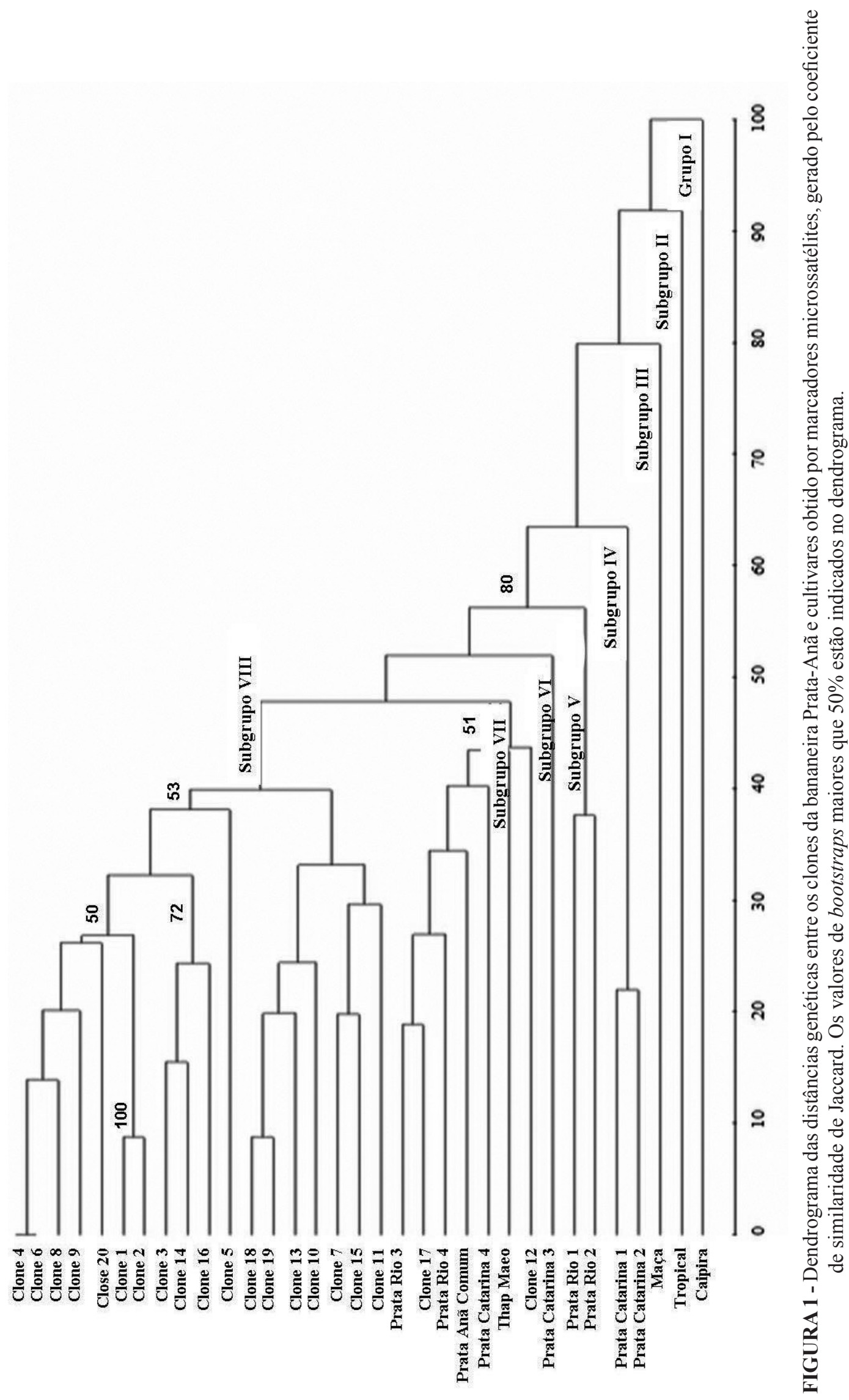




\section{CONCLUSÃO}

Os marcadores microssatélites permitiram a discriminação dos clones de 'Prata-Anã Gorutuba' em relação à bananeira cultivar Prata-Anã, indicando a existência de variabilidade genética entre os clones avaliados.

\section{AGRADECIMENTOS}

Os autores agradecem à Fundação de Amparo Pesquisa do Estado de Minas Gerais - FAPEMIG, pelo apoio financeiro, e ao $\mathrm{CNPq}$, pela concessão da bolsa.

\section{REFERÊNCIAS}

AMORIM, E.P.; REIS, R.V.; AMORIM, V.B.O.; SANTOS-SEREJO, J.A.; SILVA, S.O. Variabilidade genética estimada entre diplóides de banana por meio de marcadores microssatélites. Pesquisa Agropecuária Brasileira, Brasília, v.43, p.10451052, 2008.

BEIDLER, J.L.; HILLIARD, P.R.; RILL, R.L. Ultrasensitive staining of nucleic acids with silver. Analytical Biochemistry, New York, v.126, p.374380,1982

BOUHADIDA, M.; CASAS, M.J.; GONZALO, M.J.; ARÚS, P.; MORENO, M.A.; GOGORCENA, Y. Molecular characterization and genetic diversity of Prunus rootstocks. Scientia Horticulturae, Amsterdam, v.120, p.237-245, 2009.

CRESTE, S.; BENATTI, T.R.; ORSI, M.R.; RISTERUCCI, A.M.; FIGUEIRA, A. Isolation and characterization of microsatellite loci from a commercial cultivar of Musa acuminata. Molecular Ecology Notes, Vancouver, v.6, p.303-306, 2006.

CRESTE, S.; TULMANN NETO, A.; SILVA, S. de O.; FIGUEIRA, A. Genetic characterization of banana cultivars (Musa spp.) from Brazil using microsatellite markers. Euphytica, Wageningen, v.132, p.259-268, 2003.

CRESTE, S.; TULMANN NETO,A.; VENCOVSKY, R.; SILVA, S. de O.; FIGUEIRA, A. Genetic diversity of Musa diploid and triploid accessions from the Brazilian banana breeding program estimated by microsatellite markers. Genetic Resources and Crop Evolution, Gatersleben, v.51, p.723-733, 2004.
CROUCH, H.K.; CROUCH, J.H.; JARRET, R.L.; CREGAN, P.B.; ORTIZ, R. Segregation at microsatellite loci in haploid and diploid gametes of Musa. Crop Science, Madison, v.38, p.211-217, 1998.

CRUZ, C. D. Programa genes: análise multivariada e simulação. Viçosa: UFV, 2006. 175p.

DOYLE, J.J.; DOYLE, J.L. Isolation of plant DNA from fresh tissue. Focus, Rockville, v.12, n.1, p.1315, 1990 .

HWANG, S.C.; KO, W.H. Cavendish banana cultivars resistant to Fusarium wilt acquired through somaclonal variation in Taiwan. Plant Disease, Davis, v.88, p.580-588, 2004.

IPGRI- International Plant Genetic Resources Institute. Descriptors for banana (Musa spp.). Rome: FAO, IPGRI, INIBAP, 1996. 55p.

JESUS, O.N.; FERREIRA, C.F.; SILVA, S.O.; CAMARA, T.R.; SOARES, T.L.; PESTANA, K.N. Characterization of recommended banana cultivars using morphological and molecular descriptors. Crop Breeding and Applied Biotechnology, Viçosa, MG, v. 9, p.164-173, 2009.

KAEMMER, D.; FISCHER, D.; JARRET, R.L.; BAURENS, F.C.; GRAPIN, A.; DAMBIER, D.; NOYER, J.L.; LANAUD, C.; KAHL, G.; LAGODA, P.J.L. Molecular breeding in genus Musa: a strong case for STMS marker technology. Euphytica, Wageningen, v.96, p.49-63, 1997.

LAGODA, P.J.L.; NOYER, J.L.; DAMBIER, D.; BAURENS, F.C.; GRAPIN, A.; LANAUD, C. Sequence tagged microsatellite site (STMS) markers in the Musaceae. Molecular Ecology, Vancouver, v. 7, n.5, p.657-666, 1998

LICHTEMBERG, L.A; LICHTEMBERG, P.S.F Avanços na bananicultura brasileira. Revista Brasileira de Fruticultura, Jaboticabal, v. 33, n.1, p. 29-36, 2011. Edição especial.

LICHTEMBERG, L. A.; MOREIRA, R. S. The history and characteristics of the 'Enxerto' banana. In: REUNIÃO INTERNACIONAL ACORBAT, 17., 2006, Joinville. Anais... Joinville: ACORBAT/ ACAFRUTA, 2006. v.2, p.885-887. 
MALONE, G.; ZIMMER, P.D.; CASTRO, M.A.S.; ARIAS, L.N.; MENEGHELLO, G.E.; PESKE, S.T. Caracterização bioquímica e molecular de acessos de arroz vermelho coletados no estado do rio grande do sul. Pesquisa Agropecuária Tropical, Goiania, v.37, n. 2, p.77-85, 2007.

NING, S.P.; XU, L.B.; LU, Y.; HUANG, B.Z.; GE, X.J. Genome composition and genetic diversity of Musa germplasm from China revealed by PCRRFLP and SSR markers. Scientia Horticulturae, Amsterdam, v.114, p.281-288, 2007.

RODRIGUES, F. E.; LIBRELON S.S.; NIETSCHE, S.; COSTA, M.R.; PEREIRA, M.C.T. Genetic variability in clones of 'Prata Anã' bananas based on phenotypic and molecular markers. Bragantia, Campinas, v.72. n.2, p.182-189 2012.

RODRIGUES, M.G.V.; DONATO, S.L.R.; DIAS, M.S.C.; SILVA, J.T.A.; REIS, J.B.R.S. Banana. Informe Agropecuário, Belo Horizonte, v. 32, n.264, p.35-48, 2011.

SILVA, S. de O; SANTOS-SEREJO, J.A. dos; CORDEIRO, Z.J.M. Variedades. In: BORGES, A.L.; SOUZA, L. da S. (Ed.). O cultivo da bananeira. Cruz das Almas: Embrapa Mandioca e Fruticultura, 2004. p.45-58.

SONIYA, E.V.; BANERJEE, N.S.; DAS, M.R. Genetic analysis of somaclonal variation among callus-derived plants of tomato. Current Science, Bangalore, v.80:1213-1215, 2001.
SOUZA, C.M.P.; VIANA, A.P.; FERREIRA, C.F.; SILVA, S.O.; CARVALHO, A.J.C.; BERBERT, P.A.;SOUZA, E.F. Avaliação da dissimilaridade genética em genótipos de bananeira (Musa spp.) via marcadores RAPD. Revista Brasileira de Fruticultura, Jaboticabal, v.30, n.2, p. 419-424, 2008.

SOUZA, S. A. C. Avaliação da variabilidade genética em Musa spp. utilizando marcadores Microssatélites. 2002. 86f. Tese (Doutorado) Escola Superior de Agricultura Luiz de Queiroz, universidade de São Paulo, Piracicaba, 2002.

VENKATACHALAM, L.; SREEDHAR, R.V.; BHAGYALAKSHMI, N.Molecular analysis of genetic stability in long-term micropropagated shoots of banana using RAPD and ISSR markers. Electronic Journal of Biotechnology, Valparaíso, v.15, p.106-113, 2007.

WANG, J.Y.; ZHENG, L.S.; HUANG, B.Z.; LIU, W.L.; WU, Y.T. Development, characterization, and variability analysis of microsatellites from a commercial cultivar of Musa acuminata. Genetic Resources and Crop Evolution, Gatersleben, v.57, p.553-563, 2010.

WEILER, R.L.; BRUGNARA, E.C.; SCHWARZ, S.F.; BASTIANEL, M.; MACHADO, M.A.; SCHIFINO-WITTMANN, M.T. Caracterização molecular de uma progênie de tangerineira 'Clementina Fina' e 'Montenegrina'. Ciência Rural, Santa Maria, v.40, n.7, p.1523-1529, 2010. 